\title{
Impact of Hereditary Hemorrhagic Teleangiectasia on Quality of Life
}

\author{
Martin Holderried, Manuela Baur and Markus Pfister
}

University of HNO Klinik Tuebingen, Elfriede Aulhornstr.5, D-72076 Tuebingen, Germany

\begin{abstract}
Hereditary hemorrhagic telangiectasia (HHT) is an autosomal dominantly inherited disorder of the fibrovascular tissue. The most common symptoms are recurrent nose bleeds and multiple mucocutaneous telangiectases. Arteriovenous malformations (AVMs) are less obvious. Because there is no permanent cure available, patients often suffer from mental stress. Several studies have been performed to assess the quality of life (QoL) of HHT patients. These studies showed that HHT patients rated bodily pain lower than the general population but altogether they had lower health-related QoL.
\end{abstract}

Keywords: Morbus osler-rendu, quality of life, septodermoplasty, laser treatment, epistaxis, genotype.

\section{INTRODUCTION}

Hereditary hemorrhagic telangiectasia (HHT) or OslerWeber-Rendu syndrome is a genetic disorder of the fibrovascular tissue. Rendu [1] first described it as a disease of the skin and the mucosa in 1896 and Osler [2] was the first to describe the affection of the viscera in 1901. Weber (1907) [3] and Hanes (1909) [4] introduced the term "hereditary hemorrhagic telangiectasia".

HHT is inherited in an autosomal dominant way with an estimated prevalence between 1:2,500 and 1:40,000 in all races and all parts of the world [5-7]. So far three genes which can cause HHT have been identified. Endoglin $(E N G)$ on Chromosome 9q33-q34 in HHT Type 1 [8], activin receptor-like kinase 1 gene (ACVRL1) on Chromosome 12q13 in HHT Type 2 [9] and SMAD4 on Chromosome 18q21.1 in a rare syndrome consisting of juvenile polyposis and HHT [10]. An additional locus on chromosome 5 (HHT3) [11] has been described in 2005. Genetic diagnostics are difficult and expensive because there are no mutation hot spots and each family has its own mutation.

Spontaneous and recurrent epistaxis is frequently the first [12], the most common and leading symptom. It occurs in up to $96 \%$ of patients [5,13-15] Multiple mucocutaneous telangiectases on hands, face, lips and oral cavity years after the first nose bleeds are the most common signs [16]. Further more less obvious arteriovenous malformations (AVMs) in the lung, the brain, the liver or the gastrointestinal tract with life-threatening stroke or hemorrhage may occur $[17,18]$. The phenotype of HHT patients is highly variable. For the clinical diagnosis of HHT in 2000 the Curaçao Criteria consensus clinical diagnostic criteria - were established [15] (Table 1).

When three or more of these criteria are present and blood-clotting disorders are excluded, the diagnosis of HHT becomes definite. If two are present the diagnosis is possible or suspected and if less than two criteria are present the diagnosis of HHT is unlikely. For children and young adults

*Address correspondence to this author at the University of HNO Klinik Tuebingen, Elfriede Aulhornstr.5, D-72076 Tuebingen, Germany; Tel: +497071-2988088; Fax: +49-7071-293311; E-mail: mpfister@onlinehome.de
Table 1. Curaçao Criteria

\begin{tabular}{|l|l|}
\hline \multicolumn{1}{|c|}{ Criteria } & \multicolumn{1}{c|}{ Description } \\
\hline \hline Epistaxis & Spontaneous and recurrent \\
\hline Telangiectases & $\begin{array}{l}\text { Multiple, at characteristic sites: lips, oral cavity, } \\
\text { fingers, nose }\end{array}$ \\
\hline Visceral lesions & $\begin{array}{l}\text { GI-Telangiectasia, pulmonary, hepatic, cerebral or } \\
\text { spinal AVMs }\end{array}$ \\
\hline Family history & $\begin{array}{l}\text { A first degree relative with HHT according to these } \\
\text { criteria }\end{array}$ \\
\hline
\end{tabular}

in HHT families, who do not meet the Curaçao Criteria, genetic testing is useful.

Recurrent nosebleeds often start before the age of $20[5,12]$ get worse and lead to anaemia over years. There are a multitude of invasive [19-23] and non-invasive [20,22] therapies for acute and chronic recurrent epistaxis but no long-lasting cure with a significant improvement in hemoglobin.

$80 \%$ of the patients develop telangiectasia of the gastrointestinal tract [24] and about one fourth develop significant gastrointestinal bleeding, in the majority of cases at higher age $[18,25,26]$. Hormonal therapy [27], anti-fibrinolytics as well as endoscopic surgery [28] are common treatment options for recurrent gastrointestinal bleeding.

Cerebral vascular malformation (CVM) occurs in almost $23 \%$ of HHT patients [29] often in young age [30]. To avoid debilitating complications by using effective treatment options like microsurgery, embolotherapy, stereotactic radiation [31] or a combination of these, screening for CVMs in HHT patients by MRI is useful.

Pulmonary arteriovenous malformations (PAVMs) show frequently no clinical symptoms until the development of severe complications. Transthoracic contrast echocardiography therefore is a screening method with a high sensitivity [32] and embolization is a safe and effective treating method [33].

Symtoms caused by liver vascular malformations (LVMs) are also uncommon in HHT patients but can cause highoutput heart failure, portal hypertension and biliary necrosis 
[34]. Doppler Ultrasound has a positive predictive value close to $100 \%$ for LVMs in HHT patients [35]. Embo-lization is effective in improving symptoms temporarily but can cause severe side effects like liver transplantation [36].

The mortality in HHT patients seems to be elevated. Especially in patients younger than 60 years of age mainly nosebleeds and gastrointestinal bleeding are responsible for the mortality rate of one third in HHT patients.

Since a permanent cure of the disease is not available and symptoms tend to recur, HHT patients often visit medical professionals of necessity and may suffer from mental stress. So far quality of life (QoL) aspects have only been analyzed in a limited number of studies.

Quality of life itself is an extensive construct for evaluating the general well-being of individuals and societies.

In 1991 the World Health Organization Quality of Life (WHOQOL) project was initiated for an international quality of life assessment. They define quality QoL as "individuals" perception of their position in life in the context of the culture and value systems in which they live and in relation to their goals, expectations, standards and concerns" [37]. There are more than 1000 "Health-related-quality-of-lifetests" [38] but only a few of them are suitable for significant, valid and comparable studies [38].

In HHT, to our knowledge, only a few studies on healthrelated quality of life have been done so far [39-44]. The evaluation was done with the Short Form-36 Health Survey (SF-36). This is a generic multi-purpose health survey questionnaire. It consists of 36 questions and was designed for patients with somatic and psychological diseases to measure the subjective perception of health as in the context of health-related Quality of Life (HR-QoL). Therefore the questionnaire contains scores for physical functioning $(\mathrm{PF})$, physical role limitations (RP), bodily pain (BP), general health (GH), vitality (VT), social functioning (SF), emotional role limitations (RE), and mental health (MH), and one additional index for health transition (HT). The health transition index stands for state of health in relation to the year before. All scores range from 0 (worst) to 100 (best). For the international HR-QoL the SF-36 has been proven to be suitable especially in surveys of general and specific populations for differentiating health benefits caused by various treatments and for comparing the relative burden of diseases and it is the most widely proven instrument in patient-assessed health measure [45]. The HR-QoL was evaluated in 50 Italian [40], 38 British [39] and 171 (94 + 77) $[43,44]$ German HHT-patients by using the SF-36. The German group investigated as well the impact of the Genotypes HHT1 and HHT 2 on HR-QoL. Two other studies, one from Greece, followed 27 HHT-patients with epistaxis [41] and a second British study followed 29 patients [42] and investigated the impact of different treatment options for expistaxis in QoL of HHT-patients. The first four mentioned studies showed that HHT-patients, no matter which genotype, rated the domain of bodily pain lower than the general population. But they altogether had lower HR-QoL with respect to the control groups. The clinical variables and their influence on HR-QoL obtained in the multivariable studies were different and therefore limited comparable.
Karapantzos et al. [41] looked primarily at the influence of Nd:YAG laser application in HHT patients with recurrent epistaxis. 27 HHT patients ( 11 females, 16 males, mean age $52 \pm 3,2$ years, range 47-62 years) based on the Curaçao criteria family history, epistaxis, mucocutaneous telangiectases, and arteriovenous malformations were enrolled in that study. The haemoglobin level was below $10 \mathrm{~g} / \mathrm{dl}$ in all patients and according to the need of one or more blood transfusions because of epistaxis during their past medical history, the patients were divided in two groups: One group with "mild to moderate" disease and one group with "severe" disease. The Nd:YAG laser procedures were performed under general anesthesia. 8 patients $(30 \%)$ received only $1 \mathrm{Nd}: Y A G$ laser procedure, $15(56 \%)$ had 2 treatments and $4(14 \%)$ had 3 treatments. Unfortunately the study does not mention the influence of "mild to moderate" or "severe" disease for the number of laser therapies and the consequences for HR-QoL. To measure the influence of the treatment on HR-QoL, the SF-36 was given to the patients just before the first Nd:YAG procedure and 24 months after that first procedure. Karapantzos et al. [41] measured a significant increase in physical and mental health in HHT patients after epistaxis treatment with Nd:YAG laser. The study results with HRQoL scores are shown in Table 2.

Table 2. QoL Scores in HHT Patients Just Before and 2 Years After Nd:YAG Laser Treatment Using the Mann-Whity U Test. Data are Shown as Mean \pm Standard Error (SE)

\begin{tabular}{|l|c|c|c|}
\hline & $\begin{array}{c}\text { Before } \\
\text { Treatment }\end{array}$ & $\begin{array}{c}\text { After } \\
\text { Treatment }\end{array}$ & P Value \\
\hline \hline Physical functioning (PF) & $32.7 \pm 2.1$ & $49.8 \pm 2.3$ & $\mathrm{P}=0.03$ \\
\hline $\begin{array}{l}\text { Role limitations due to } \\
\text { physical problems (RP) }\end{array}$ & $36.5 \pm 1.5$ & $51.5 \pm 2.1$ & $\mathrm{P}=0.04$ \\
\hline Bodily pain (BP) & $41.5 \pm 2.9$ & $44.9 \pm 3.2$ & $\mathrm{NS}$ \\
\hline General health perceptions (GH) & $42.4 \pm 1.6$ & $44.1 \pm 2.7$ & $\mathrm{NS}$ \\
\hline Physical Health Dimension (PHD) & $38.1 \pm 2.3$ & $47.5 \pm 2.9$ & $\mathrm{P}=0.04$ \\
\hline Vitality (VT) & $36.6 \pm 2.7$ & $47.8 \pm 2.4$ & $\mathrm{P}=0.03$ \\
\hline Social functioning (SF) & $34.5 \pm 3.1$ & $49.1 \pm 2.8$ & $\mathrm{P}=0.04$ \\
\hline $\begin{array}{l}\text { Role limitations due to } \\
\text { emotional problems (RE) }\end{array}$ & $42.1 \pm 1.9$ & $43.1 \pm 1.8$ & $\mathrm{NS}$ \\
\hline General mental health (MH) & $43.4 \pm 2.6$ & $44.9 \pm 1.7$ & $\mathrm{NS}$ \\
\hline Mental Health Dimension (MHD) & $39.6 \pm 2.4$ & $45.1 \pm 2.7$ & $\mathrm{P}=0.04$ \\
\hline
\end{tabular}

Hitchings et al. [42] investigated in 29 HHT patients (14 males, 15 females, mean age 56, range 18-78 years) with recurrent epistaxis the effect of nasal closure, argon laser treatment and a combination of septodermoplasty and argon laser treatments on HR-QoL. The SF-36 was given to the patients before and in the mean 22 months postoperatively (range 10-32 months). 8 patients underwent nasal closure, 15 patients underwent the argon laser treatment, and 6 patients were treated with a combination of argon laser and unilateral septodermoplasty (worst affected side). All patients treated with nasal closure had previous laser treatments and showed a significant $(\mathrm{p}<0.05)$ improvement for physical functioning and general health perception after nasal closure. The argon 
laser group and the combined argon laser with septodermoplasty groups showed no significant improvement in HRQoL after treatment. In the argon laser group $72 \%$ of HHTpatients had no improvement of the bleeding frequency and severity and in $14 \%$ the bleeding severity increased postoperatively. $66 \%$ of the patients in the combined treatment group felt some subjective improvement and 33\% complained about more severe bleeding. In the nasal closure group patients did not complain about dryness and sore throats and there was no difference between pre- and postoperative pain domain scores in the SF-36.

Lennox et al. [39] looked at the HR-QoL according to epistaxis and blood transfusions in 38 HHT-patients (20 male, 18 female, mean age 60, range 18-78) and compared it to the population norm in the UK. The SF-36 showed no significant difference for bodily pain, all other dimensions were significantly reduced in HHT-patients. They also rated epistaxis as mild, moderate, and severe and found no significant difference between the mild and the moderate group. In the severe epistaxis group the scores for physical functioning, health perception, energy, and social functioning were significantly lower. Interestingly they could not detect any correlation between the SF-36 scores and the number of blood transfusions required.

Pfister et al. [43] investigated the impact of genotype and mutation type on HR-QoL in HHT-patients using the SF-36. 94 HHT-patients with definite diagnoses of HHT were enrolled (41 male, 53 female, mean age 59, range 23-89). The genetic sequencing was done in 24 patients ( 9 male, 15 female, mean age 62, range 23-78). The genotype analyses showed 11 HHT Type 1 patients (3 male, 8 female, mean age 59.3) and 13 HHT Type 2 patients (6 male, 7 female, mean age 61.6). The SF-36 showed no significant difference between the two genotypes in the scales vitality, emotional and mental role. The physical components including physical functioning, physical role limitations, bodily pain, and general health was rated 10 points higher in
HHT2 patients than in HHT1 patients. The SF-36 results of all HHT patients are shown on Table 3. Pfister et al. [43] also showed that both genotype groups rated bodily pain lower $(>50)$ than the general German population.

Pasculli G. et al. [40] compared the HR-QoL in 50 HHT patients (27 male, 23 female, mean age 47.6, range 19-75) with 2301 normal Italian subjects (49\% male, 51\% female, mean age 47.7) using the SF-36. Clinical variables in this study have been patient age, illness duration, haemoglobin levels and number of epistaxis episodes 12 months before study enrolment. The physical health and mental health scores were significantly lower in HHT patients. No difference could be shown in the bodily pain score (Table $\mathbf{5}$ ).

The scores showed significant gender-related differences in HHT patients for physical functioning, physical role limitations, bodily pain, social functioning, emotional role limitations, and physical component summary (Table 4).

With increasing age physical functioning, physical role limitations, bodily pain, and emotional role limitations were significantly lower. An increasing number of epistaxis was associated with worsened physical role limitations, vitality, social functioning, physical component score, and bodily pain. With longer illness duration, the mental component score gets worse and with lower haemoglobin levels the physical functioning. Interestingly, no clinical variable shows a relation to general health and mental health scores (Table 6).

Geisthoff et al. [44] investigated the HR-QoL in 77 HHT patients (41 male, 36 female, mean age 57.2, range 13-85) who fulfilled at least two Curaçao Criteria and compared the results with 2877 normal German subjects $(49.4 \%$ male, $55.6 \%$ female, mean age 47.7 ). They used the SF-36 and a second questionnaire with three opened questions to specify the HHT-related restrictions in athletic activities, reasons for psychological strain and reasons for severe consequences in professional life. In addition they included more clinical and

Table 3. HR-QoL Scores in HHT-Patient Samples with and without Genetic Testing

\begin{tabular}{|c|c|c|c|c|}
\hline Age (years) & $56 \pm 13.3$ & $60.5 \pm 12.3$ & $55.5 \pm 13.4$ & NS \\
\hline Gener: male/female & $41 / 43$ & $9 / 15$ & $32 / 38$ & NS \\
\hline Role limitations due to physical problems (RP) & $55.6 \pm 44.6$ & $53.1 \pm 43.8$ & $56.4 \pm 45.2$ & NS \\
\hline Bodily pain (BP) & $74.1 \pm 29.6$ & $73.8 \pm 29.8$ & $74.2 \pm 29.7$ & NS \\
\hline General health perceptions (GH) & $47.7 \pm 20.9$ & $53.0 \pm 20.5$ & $45.9 \pm 20.9$ & NS \\
\hline Vitality (VT) & $46.1 \pm 21.6$ & $43.3 \pm 21.3$ & $47.1 \pm 21.7$ & NS \\
\hline Physical component summary score (PCS) & $46.0 \pm 12.0$ & $47.1 \pm 12.5$ & $45.7 \pm 11.9$ & NS \\
\hline Mental component summary score (MCS) & $42.3 \pm 12.7$ & $43.9 \pm 12.3$ & $41.8 \pm 12.9$ & NS \\
\hline
\end{tabular}


Table 4. HR-QoL Scores and Clinical Variables in male and female HHT-Patients

\begin{tabular}{|c|c|c|c|}
\hline & Males & Females & P Value \\
\hline $\mathrm{N}$ & 27 & 23 & \\
\hline Age, mean \pm SD & $46.6 \pm 13.0$ & $48.7 \pm 16.9$ & NS \\
\hline Years of disease & $25.4 \pm 16.0$ & $24.7 \pm 13.2$ & NS \\
\hline Number of epistaxis & $189 \pm 240$ & $274 \pm 288$ & NS \\
\hline $\mathrm{Hb}$ in $\mathrm{g} / \mathrm{dl}$ & $12.9 \pm 2.1$ & $12.0 \pm 2.4$ & NS \\
\hline$\%$ anaemia $(\mathrm{Hb}$ male $<12 \mathrm{~g} / \mathrm{dl}, \mathrm{Hb}$ female $<13,5 \mathrm{~g} / \mathrm{dl})$ & 51.9 & 39.1 & NS \\
\hline Physical functioning (PF) & $81.3 \pm 22.6$ & $69.1 \pm 27.8$ & $\mathrm{P}<0.05$ \\
\hline Role limitations due to physical problems (RP) & $62.5 \pm 37.6$ & $38.0 \pm 41.9$ & $\mathrm{P}<0.02$ \\
\hline Bodily pain (BP) & $82.3 \pm 22.0$ & $67.3 \pm 30.6$ & $\mathrm{P}<0.03$ \\
\hline General health perceptions $(\mathrm{GH})$ & $43.4 \pm 22.9$ & $36.0 \pm 24.6$ & NS \\
\hline Vitality (VT) & $46.5 \pm 17.5$ & $43.6 \pm 15.9$ & NS \\
\hline Social functioning (SF) & $67.1 \pm 27.0$ & $54.6 \pm 22.4$ & $\mathrm{P}<0.05$ \\
\hline Role limitations due to emotional problems (RE) & $65.4 \pm 37.2$ & $31.9 \pm 44.4$ & $\mathrm{P}<0.005$ \\
\hline General mental health (MH) & $60.5 \pm 24.9$ & $57.9 \pm 21.1$ & NS \\
\hline Physical component summary score (PCS) & $49.7 \pm 8.1$ & $43.8 \pm 10.5$ & $\mathrm{P}<0.02$ \\
\hline Mental component summary score (MCS) & $39.6 \pm 11.4$ & $37.7 \pm 12.8$ & NS \\
\hline
\end{tabular}

Table 5. HR-QoL Scores in HHT-Patients and normal Italian Population

\begin{tabular}{|c|c|c|c|}
\hline Age, mean & 47.6 & 47.7 & NS \\
\hline Physical functioning (PF) & $72.6 \pm 25.7$ & $84.5 \pm 23.2$ & $\mathrm{P}<0.0002$ \\
\hline Role limitations due to physical problems (RP) & $51.0 \pm 41.1$ & $78.2 \pm 35.9$ & $\mathrm{P}<0.0001$ \\
\hline Bodily pain (BP) & $75.3 \pm 27.2$ & $73.3 \pm 27.6$ & NS \\
\hline Vitality (VT) & $45.1 \pm 16.6$ & $61.8 \pm 20.7$ & $\mathrm{P}<0.0001$ \\
\hline Social functioning (SF) & $61.2 \pm 25.5$ & $77.4 \pm 23.3$ & $\mathrm{P}<0.0001$ \\
\hline Role limitations due to emotional problems (RE) & $49.6 \pm 43.7$ & $76.2 \pm 37.2$ & $\mathrm{P}<0.0001$ \\
\hline General mental health $(\mathrm{MH})$ & $59.3 \pm 23.0$ & $66.6 \pm 20.9$ & $\mathrm{P}<0.01$ \\
\hline
\end{tabular}

Table 6. Clinical Variables and their influence for the HR-QoL in 50 HHT-Patients

\begin{tabular}{|c|c|c|c|}
\hline & Variables & Partial Correlation (- Indicates a Relation to Lower HR-QoL) & P Value \\
\hline Physical functioning (PF) & $\begin{array}{l}\mathrm{Age} \\
\mathrm{Hb}\end{array}$ & $\begin{array}{l}-0.315 \\
+0.331\end{array}$ & $\begin{array}{l}\mathrm{P}<0.04 \\
\mathrm{P}<0.03\end{array}$ \\
\hline Role limitations due to physical problems (RP) & $\begin{array}{c}\text { Age } \\
\text { N. of epistaxis }\end{array}$ & $\begin{array}{l}-0.366 \\
-0.363\end{array}$ & $\begin{array}{l}\mathrm{P}<0.008 \\
\mathrm{P}<0.009\end{array}$ \\
\hline Bodily pain (BP) & $\begin{array}{c}\text { Age } \\
\text { N. of epistaxis }\end{array}$ & $\begin{array}{l}-0.291 \\
-0.391\end{array}$ & $\begin{array}{l}\mathrm{P}<0.05 \\
\mathrm{P}<0.01\end{array}$ \\
\hline General health perceptions (GH) & $\mathrm{xxx}$ & $\mathrm{xxx}$ & NS \\
\hline Vitality (VT) & N. of epistaxis & -0.441 & $\mathrm{P}<0.002$ \\
\hline Social functioning (SF) & N. of epistaxis & -0.473 & $\mathrm{P}<0.001$ \\
\hline Role limitations due to emotional problems (RE) & Age & -0.391 & $\mathrm{P}<0.01$ \\
\hline General mental health (MH) & $\mathrm{xxx}$ & $\mathrm{xxx}$ & NS \\
\hline Physical component summary score (PCS) & N. of epistaxis & -0.488 & $\mathrm{P}<0.001$ \\
\hline Mental component summary score (MCS) & Years of disease & -0.421 & $\mathrm{P}<0.004$ \\
\hline
\end{tabular}


Table 7. Clinical and Psychological Variables in HHT-Patients

\begin{tabular}{|l|l|c|}
\hline \multicolumn{1}{|c|}{ Variables } & N (Answers) & N Yes (Answers with Yes) \\
\hline \hline Presesence of epistaxis & 72 & 69 \\
\hline Presence of telangiectases & 75 & 75 \\
\hline Gastrointestinal bleeding & 48 & 11 \\
\hline Liver manifestation & 39 & 7 \\
\hline Pulmonary arterious malformation & 40 & 9 \\
\hline Cerebral vascular malformation & 39 & 31 \\
\hline Dyspnea & 62 & 40 \\
\hline Restriction in athletic activities & 54 & 8 \\
\hline Change of profession because of HHT & 47 & 22 \\
\hline Pension claim because of HHT & 66 & 30 \\
\hline Social contacts reduced because of HHT & 67 & 9 \\
\hline Use of professional psychological support & 67 & 16 \\
\hline Influence on family planning & 60 & \\
\hline
\end{tabular}

Table 8. HR-QoL Scores in HHT-Patients and normal German Population

\begin{tabular}{|c|c|c|c|}
\hline & HHT-Patients & Normal Germans & P Value \\
\hline $\begin{array}{l}\text { Physical functioning }(\mathrm{PF}) \\
\text { Total } \\
\text { Male } \\
\text { Female }\end{array}$ & $\begin{aligned} 64.74 & \pm 26.27 \\
70.49 & \pm 23.84 \\
58.19 & \pm 27.68\end{aligned}$ & $\begin{array}{l}80.14 \pm 22.03 \\
82.03 \pm 21.28 \\
78.09 \pm 22.92\end{array}$ & $\begin{array}{l}\mathrm{P}<0.001 \\
\mathrm{P}<0.001 \\
\mathrm{P}<0.001\end{array}$ \\
\hline $\begin{array}{l}\text { Role limitations due to physical problems (RP) } \\
\text { Total } \\
\text { Male } \\
\text { Female }\end{array}$ & $\begin{array}{c}56 \pm 44.62 \\
60 \pm 43.04 \\
51.43 \pm 46.55\end{array}$ & $\begin{array}{l}78.48 \pm 31.49 \\
79.83 \pm 30.91 \\
77.02 \pm 32.48\end{array}$ & $\begin{array}{l}\mathrm{P}<0.001 \\
\mathrm{P}<0.001 \\
\mathrm{P}<0.001\end{array}$ \\
\hline $\begin{array}{l}\text { Bodily pain }(\mathrm{BP}) \\
\text { Total } \\
\text { Male } \\
\text { Female }\end{array}$ & $\begin{array}{c}72.21 \pm 30.96 \\
81.5 \pm 24.33 \\
61.89 \pm 34.45\end{array}$ & $\begin{array}{l}74.11 \pm 25.59 \\
76.31 \pm 25.29 \\
71.38 \pm 26.05\end{array}$ & $\begin{array}{l}P=0.536 \\
P=0.357 \\
P=0.078\end{array}$ \\
\hline $\begin{array}{l}\text { General health perceptions }(\mathrm{GH}) \\
\text { Total } \\
\text { Male } \\
\text { Female }\end{array}$ & $\begin{array}{c}41.31 \pm 21.7 \\
50.24 \pm 20.69 \\
43.97 \pm 22.62\end{array}$ & $\begin{array}{l}62.38 \pm 18.32 \\
62.57 \pm 18.73 \\
62.17 \pm 18.13\end{array}$ & $\begin{array}{l}\mathrm{P}<0.001 \\
\mathrm{P}<0.001 \\
\mathrm{P}<0.001\end{array}$ \\
\hline $\begin{array}{l}\text { Vitality (VT) } \\
\text { Total } \\
\text { Male } \\
\text { Female }\end{array}$ & $\begin{array}{l}45.65 \pm 20.84 \\
51.46 \pm 20.59 \\
39.03 \pm 19.34\end{array}$ & $\begin{array}{c}61.53 \pm 16.99 \\
63.78 \pm 16.94 \\
59.1 \pm 16.94\end{array}$ & $\begin{array}{l}\mathrm{P}<0.001 \\
\mathrm{P}<0.001 \\
\mathrm{P}<0.001\end{array}$ \\
\hline $\begin{array}{l}\text { Social functioning }(\mathrm{SF}) \\
\text { Total } \\
\text { Male } \\
\text { Female }\end{array}$ & $\begin{array}{c}71.1 \pm 27.3 \\
72.56 \pm 25.95 \\
69.44 \pm 29.04\end{array}$ & $\begin{array}{l}87.31 \pm 16.96 \\
88.51 \pm 16.22 \\
86.01 \pm 17.86\end{array}$ & $\begin{array}{l}\mathrm{P}<0.001 \\
\mathrm{P}<0.001 \\
\mathrm{P}<0.001\end{array}$ \\
\hline $\begin{array}{l}\text { Role limitations due to emotional problems (RE) } \\
\text { Total } \\
\text { Male } \\
\text { Female }\end{array}$ & $\begin{array}{l}64.86 \pm 42.34 \\
74.56 \pm 36.71 \\
54.63 \pm 45.88\end{array}$ & $\begin{array}{l}88.94 \pm 24.67 \\
89.86 \pm 24.49 \\
87.96 \pm 25.16\end{array}$ & $\begin{array}{l}\mathrm{P}<0.001 \\
\mathrm{P}<0.001 \\
\mathrm{P}<0.001\end{array}$ \\
\hline $\begin{array}{l}\text { General mental health }(\mathrm{MH}) \\
\text { Total } \\
\text { Male } \\
\text { Female }\end{array}$ & $\begin{array}{c}61.51 \pm 21.53 \\
67.22 \pm 22.47 \\
55 \pm 18.65\end{array}$ & $\begin{array}{l}73.93 \pm 14.98 \\
76.31 \pm 14.51 \\
71.37 \pm 15.26\end{array}$ & $\begin{array}{l}\mathrm{P}<0.001 \\
\mathrm{P}<0.001 \\
\mathrm{P}<0.001\end{array}$ \\
\hline
\end{tabular}


psychological variables (Table 7) investigated them sexdependent and graded them for a more differentiated analysis in the HR-QoL (Table 7). The grading was used for number of telangiectases, impediments from telangiectases, strain on profession, strain on private life, strain on psyche, illness duration, frequency of epistaxis, average duration of epistaxis, subjective impediment from epistaxis, and worries about having HHT. Except for bodily pain HHT-patients showed significant lower scores on all scales in the HR-QoL (Table 8). The largest difference could be observed for the emotional role limitations. In HHT-patients the number of telangiectases and the duration of nosebleeds worsened physical functioning, physical role limitations, and general health significantly. Frequency of nosebleeds did not have any significant influence with any scale. The presence of cerebral and pulmonary involvement correlated significantly with emotional role limitations and physical functioning. Hepatic manifestations worsened all scales. This study also shows a correlation on "worries about having HHT" with the strain on the psyche, private life and profession.

Based on this information a limitation of life quality in almost all dimensions is associated with the amount of symptoms in HHT patients.

\section{REFERENCES}

[1] Rendu M. Épistaxis répétées chez un sujet porteur de petits angiomes cutanés et muqueux. Bull Soc Méd Hôp 1986; 13: 731-73.

[2] Osler W. On a family form of recurring epistaxis, associated with multiple telangiectases of the skin and mucous membranes. Johns Hopkins Hosp Bull 1901; 12: 333-37.

[3] Weber FP. Multiple hereditary developmentalangiomata (telangiectases) oft he skin and mucous membranes associated with recurring haemorrhages. Lancet 1907; 2:160-62.

[4] Hanes FM. Multiple hereditary telangiectases cause hemorrhage (hereditary hemorrhagic telangiectasia). John Hopkins Bull 1909; 20:63-73.

[5] Plauchu H, de Chadarevian JP, Bideau A, Robert JM. Age-related clinical profile of hereditary hemorrhagic telangiecasia in an epidemiologically recruited population. Am J Med Genet 1989; 32: 291-97.

[6] Porteous ME, Burn J, Proctor SJ. Hereditary haemorrhagic telangiectasia: a clinical analysis. J Med Genet 1992; 29: 527-30.

[7] Kjeldsen AD, Vase P, Green A. Hereditary haemorrhagic telangiectasia: a population-based study of prevalence and mortality in Danish patients. J Intern Med 1999; 245(1): 31-39.

[8] McAllister KA, Grogg KM, Johnson DW, et al. Endolgin, a TGF- $\beta$ binding protein of endothelial cells, is the gene for hereditary hemorrhagic telangiectasia type 1. Nat Genet 1994; 8: 345-51.

[9] Johnson DW, Berg JN, Baldwin MA, et al. Mutations in the activin receptor-like kinase 1 gene in hereditary hemorrhagic telangiectasia type 2. Nat Genet 1996; 13: 189-95.

[10] Gallione CJ, Repetto GM, Legius E, et al. A combined syndrome of juvenile polyposis and hereditary haemorrhagic telangiectasia associated with mutatuions in MADH4 (SMAD4). Lancet 2004; 363(9412): 852-59.

[11] Cole SG, Begbie ME, Wallace GM, Shovlin CL. A new locus for hereditary haemorrhagic telangiectasia (HHT3) maps to chromosome 5. J Med Genet 2005; 42(7):577-82.

[12] Reilly PJ, Nostrant TT. Clinical manifestations of hereditary hemorrhagic telangiectasia. Am J Gastroenterol 1984; 79: 363-67.

[13] Al-Deen S, Bachmann-Harildstad G. A grading scale for expistaxis in hereditary haemorrhagic teleangectasia. Rhinology 2008; 46(4): 28184.

[14] Reilly PJ, Nostrant TT. Clinical manifestations of hereditary hemorrhagic telangiectasia. Am J Gastroenterol 1984; 79: 363-67.

[15] Shovlin CL, Guttmacher AE, Buscarini E, et al. Diagnsotic criteria for hereditary hemorrhagic telangiectasia (Rendu-Osler-Weber syndrome). Am J Med Genet 2000; 91:66-67.

[16] Fernández-Jorge B, Del Pozo Losada J, Paradela S, Martínez-González C. Treatment of cutaneous and mucosal telangiectases in hereditary hemorrhagic telangiectasia: Repot of three cases. J Cosmet Laser Ther 2007; 9(1): 29-33.

[17] White RI. Pulmonary arteriovenous malformations: how do we diagnose them and why is it important to so so? Radiology 1992; 182: 633-35.

[18] Longacre AV, Gross CP, Gallitelli M, et al. Diagnosis and management of gastronintestinal bleeding is patients with hereditary hemorrhagic telangiectasia. Am J Gastroenterol 2003; 98(1): 59-65.

[19] Shah RK, Dhingra JK, Shapshay SM. Hereditary hemorrhagic telangiectasia: a review of 76 cases. Laryngoscope 2002; 112(5): 76773.

[20] McCaffrey TV, Kern EB, Lake CF. Management of expistaxis in hereditary hemorrhagic telangiectasia. Review of 80 cases. Arch Otolaryngol 1977; 103 (11): 627-30.

[21] Mahoney EJ, Shapshay SM. Nd-YAG laser photocoagulation for epistaxis associated with hereditary hemorrhagic telangiectasia. Laryngoscope 2005: 115(2): 373-75.

[22] Bergler W, Sadick H, Gotte K, et al. Topical estrogens combined with argon plasma coagulation in the management of epistaxis in hereditary hermorrhagic telangiectasia. Ann Otol Rhinol Laryngol 2002; 111(3Pt 1): 222-28.

[23] Andersen PJ, Kjeldsen AD, Nepper-Rasmussen J. Selective embolization in the treatment of intractable epistaxis. Acta Otolaryngol 2005; 125(3): 293-97.

[24] Buscarini E, Plauchu H, Garcia Tsao G, et al. Liver involvement in hereditary hemorrhagic telangtiectasia: consensus recommendations. Liver Int 2006; 26(9): 1040-46.

[25] Memeo M, Stabile Ianora AA, Scardapane A, et al. Hereditary haemorrhagic telangiectasia: study of hepatic vascular alterations with multi-detector row helical CT and reconstruction programs. Radiol Med 2005; 109(1-2): 125-38.

[26] Buscarini E, Danesino C, Olivieri C, et al. Doppler ultrasonographic grading of hepatic vascular malformations in hereditary hemorrhagic telangiectasia - results of extensive screening. Ultraschall Med 2004; 25(5): 348-55.

[27] van Cutsem E, Rutgeerts P, Vantrappen G. Treatment of bleeding gastrointestinal vascular malformations with oestrogen-progesterone. Lancet 1990; 355(8695): 953-55.

[28] Gostout CJ, Bowyer BA, Ahlquist DA, et al. Mucosal vascular malformations of the gastrointestinal tract: clinical observations and results of endoscopic neodymium: yttrium-aluminium-garnet laser therapy. Mayo Clin Proc 1988; 63(10): 993-03.

[29] Fulbright RK, Chaloupka JC, Putman CM, et al. MR of hereditary hemorrhagic telangiectasia: prevalence and spectrum of cerebrovascular malformations. AJNR Am J Neuroradiol 1998; 19(3): 477-84.

[30] Morgan T, McDonald J, Anderson C, et al. Intracranial hemorrhage in infants and children with hereditary hemorrhagic telangiectasia (OslerWeber-Rendu syndrome). Pediatrics 2002; 109(1): E12.

[31] Matsubara S, Mandzia JL, der Brugge K, et al. Angiographic and clinical characteristics of patients with cerebral arteriovenous malformation associated with hereditary hemorrhagic telangiectasia. AJNR Am J Neuroradiol 2000; 21(6): 1016-20.

[32] Cottin V, Plauchu H, Bayle JY, et al. Pulmonary arteriovenous malformations in patients with hereditary hemorrhagic telangiectasia. Am J Respir Crit Care Med 2004; 169(9): 994-1000.

[33] Pollak JS, Saluja S, Thabet A, et al. Clinical and anatomic outcomes after embolotherapy of pulmonary arteriovenous malformations. J Vas Interv Radiol 2006; 17(1): 35-44; quiz 45.

[34] Garcia-Tsao G, Korzenik JR, Young L, et al. Liver disease in patients with hereditary hemorrhagic telangiectasia. N Engl J Med 2000; 343(13): 931-36.

[35] Caselitz M, Bahr MJ, Bleck JS, et al. Sonographic criteria fort he diagnosis of hepatic involvement in hereditary hemorrhagic telangiectasia (HHT). Hepatology 2003; 37(5): 1139-46.

[36] Chavan A, Caselitz M, Gratz KF, et al. Hepatic artery embolization for treatment of patients with hereditary hemorrhagic telangiectasia and symptomatic hepatic vascular malformations. Eur Radiol 2004; 14(11): 2079-85.

[37] WHOQOL Group. The World Health Organization Quality of Life Assessment (WHOQOL): position paper from the world health organization. Soc Sci Med 1995; 41(10):1403-9.

[38] Gaul G. Quality of life - Therapieziel oder Schalgwort? J Kardiol 1999; 6: 617-18.

[39] Lennox PA, Hichings AE, Lund VJ, et al. The SF-36 health status questionnaire in assessing patients with epistaxis secondary to hereditary hemorrhagic telangiectasia. Am J Rhinol 2005; 19(1): 71-74. 
[40] Pasculli G, Resta F, Guastamacchia E, et al. Health-related quality of life in a rare disease: hereditary hemorrhagic telangiectasia (HHT) or Rendu-Osler-Weber disease. Qual Life Res 2004; 13(10): 1715-23.

[41] Karapantzos I, Tsimpiris N, Goulis DG, et al. Management of epistaxis in hereditary hemorrhagic telangiectasia by Nd:YAG laser and quality of life assessment using the HR-QoL questionnaire. Eur Arch Otorhinolaryngol 2005; 262(10): 830-33.

[42] Hitchings AE, Lennox PA, Lund VJ, et al. The effect of treatment for expistaxis secondary to hereditary hemorrhagic telangiedtasia. Am J Rhinol 2005; 19(1): 75-78.
[43] Pfister M, Zalaman IM, Blumenstock G, et al. Impact of genotype and mutation on health-related quality of life in patients with hereditary hemorrhagic telangiectasia. Acta Otolaryngol 2008; 17:1-5.

[44] Geisthoff UW, Heckmann K, D`Amelio R, et al. Health-related quality of life in hereditary hemorrhagic telangiectasia. Otolaryngol Head Neck Surg 2007; 136: 726-33.

[45] Garratt A, Schmidt L, Mackintosh A, et al. Quality of life measurement: bibliographic study of patient assessed health outcome measures. BMJ 2002; 324 (7351): 1417.

(C) Holderried et al.; Licensee Bentham Open

This is an open access article licensed under the terms of the Creative Commons Attribution Non-Commercial License (http: //creativecommons.org/licenses/by$\mathrm{nc} / 3.0 /$ ) which permits unrestricted, non-commercial use, distribution and reproduction in any medium, provided the work is properly cited. 